\title{
E-B
}

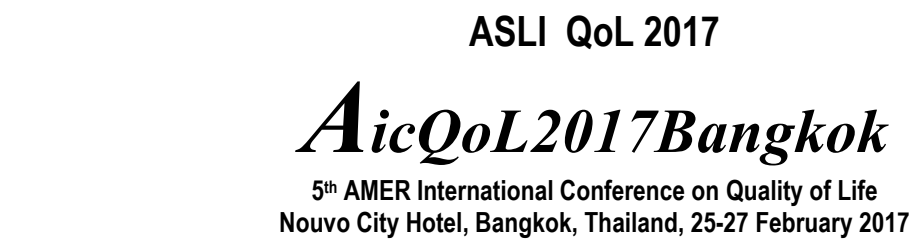

\section{Green Neighbourhood Adaptive Model for Urban Living: A Conceptual Review}

\author{
Puziah Ahmad¹, Alamah Misni1 ${ }^{1}$, Siti Mazwin Kamaruddin¹, Nurazureen Daud ${ }^{1}$ \\ ${ }^{1}$ Faculty of Architecture, Planning and Surveying, \\ Universiti Teknologi MARA, Shah Alam 40450, Malaysia
}

\begin{abstract}
Green Neighborhood can be defined as a neighborhood area that meets the needs of peoples' daily activities and allows communities to control pollution, save energy, increase employment, decrease crime rates, develop friendships, practice on-site renewable energy methods and preserve agricultural and environmentally sensitive areas. In such an environment, people make easy access to their home, workplaces, public facilities, transit facilities and green spaces within a comfortable walking scale. The guidance is aimed at assisting local authorities and agencies to implement five (5) selected green neighborhood initiatives; Provision of Pedestrian Walkway, Provision of Bicycle Lane, rainwater Harvesting System, Waste Composting and Community Farming.

Keywords: Green Neighbourhood; Environment; Community

ISSN: 2398-4287@ 2017. The Authors. Published for AMER ABRA by e-International Publishing House, Ltd., UK. This is an open access article under the CC BYNC-ND license (http://creativecommons.org/licenses/by-nc-nd/4.0/). Peer-review under responsibility of AMER (Association of Malaysian Environment-Behaviour Researchers), ABRA (Association of Behavioural Researchers on Asians) and cE-Bs (Centre for Environment-Behaviour Studies), Faculty of Architecture, Planning \& Surveying,
\end{abstract} Universiti Teknologi MARA, Malaysia.

\subsection{Introduction}

Environmental issues are undoubtedly the challenge of the 21 st century. Climate change brings the need to seriously reconsider the way cities are designed. Ongoing urbanisation and the relatively larger environmental footprint of urban inhabitants have resulted in the recognition of cities as being of fundamental importance for ambitions to achieve overall sustainable development. In fact, cities now find themselves at the very core of the "Green Revolution" as one of the main components for achieving sustainability. As a result, several urban initiatives are being put forward to make cities greener, healthier and more eco-friendly. One of these is the concept of "Green neighbourhood", which is an attempt to connect urban sustainability principles with micro-level community planning. Discourses on sustainable neighborhoods have considered the variety of tools and approaches of establishing green cities, metrics of evaluation, and the process of attuning the ecologically complex urban situation and enhancing beautiful environments to be part of the process. The ever greater impacts and real dynamics of global are denominators in creating a better human settlement in particular small neighbourhoods which are the fundamentals of creating a better world.

\subsection{Background}

Sustainability is a relationship that people have with natural resources. Sustainability is a practice. The challenge of green neighborhoods regards how evolving sustainable practices are attached with the forms, technologies, and processes of 21st-century sustainable cities. This is not a cultural change made necessary by the negative impacts of global warming. It is rather, a creative opportunity to enhance the living environment. It is also an effort to practice the green neighborhood for environmental, human rights

\footnotetext{
${ }^{*}$ Corresponding author. Tel.:

E-mail address: puzia892@salam.uitm.edu.my
}

ISSN: 2398-4287@ 2017. The Authors. Published for AMER ABRA by e-International Publishing House, Ltd., UK. This is an open access article under the CC BYNC-ND license (http://creativecommons.org/licenses/by-nc-nd/4.0/). Peer-review under responsibility of AMER (Association of Malaysian Environment-Behaviour Researchers), ABRA (Association of Behavioural Researchers on Asians) and cE-Bs (Centre for Environment-Behaviour Studies), Faculty of Architecture, Planning \& Surveying, Universiti Teknologi MARA, Malaysia.

DOI: http://dx.doi.org/10.21834/e-bpj.v2i5.690 
as the basis of intergenerational environmental justice. It argues that the rights to clean air, water, and soil should be seen as the environmental, human rights of both present and future generations.

Due to the environmental inequality where more vulnerable communities in neighbourhood environment are more likely to be exposed to higher air pollution levels is well attested by studies from many parts of the world, in particular the USA, Canada and UK (Jerrett et al., 2001, Marshall, 2008 and Richardson et al., 2013 in www.mdpi.com/journal/sustainability ). Neighborhoods are the building blocks of cities, which have their own architectural, cultural and economic systems. It is an imperative act to improve neighborhood sustainability by considering the buildings, public spaces, infrastructure, and integration among the components.It is a well-known fact that global climate change has implications on health, weather-related mortality, infectious diseases, air quality respiratory illnesses, crop yields, forest health and productivity, water supply and quality. Hence the negative implications of climate change will ultimately impact human quality of life in general.

\subsection{Aim, Objectives, and Method}

The aim of this paper is to explore an adaptive model of a framework for a green neighborhood in the Malaysian context. The objectives are specifically for identifying factors relevant to the green neighborhood ; reviewing and comparing the framework using the method of content analysis; and providing the adaptive framework that is relevant and adaptive to the local Malaysian scenario.

The study adopts the literature scooping and reviewing and various level of content analysis before arriving at the proposed adaptive framework and model for the green neighborhood for an urban living application. Neighbourhood level is the unit of study to ensure its closeness to the community and a natural scale for urban and non-urban settings.

\subsection{Definition}

\section{i. Green Neighbourhood}

There seems to be no general definition of the neighborhood in the literature. Neighborhood boundaries can be defined both objectively and subjectively. Subjectively, the mental borders of the neighborhood can be defined by residents. Residents' perception can be used to map the boundaries of neighborhoods (Hugh Barton, Grant, \& Guise, 2003 in Sharifi Ayyob, 2013). Emphasizing the significance of the pedestrian scale, Friedmann (2010, p.154, ditto) defines the neighborhood as "the area that neighbors acknowledge as their home or, as sociologists would say, as their primary space of social reproduction". When it comes to identifying the borders of the neighborhood, there might be a limited consensus between individuals. In a study conducted in Brisbane, Australia, it was found that residents define the boundaries of their neighborhoods very differently (Minnery, Knight, Byrne, \& Spencer, 2009, ditto). This indicates that definition of neighborhood is largely individually-based and not a clear identification of its size and dimension. Dover and King (2008) argue that objective measures such as discernible center and edges, walkable size, mixed-use, network of walkable streets, and civic centers are fundamental for defining the neighborhood. Neighborhoods can also be defined using the administrative boundaries such as existing wards or districts (Hugh Barton et al., 2003; Dempsey, Brown, \& Bramley, 2012, ditto), and census collection districts (Minnery et al., 2009, ditto).

Arshad (2012, in www.mdpi.com/journal/sustainability) defined the green neighborhood as a planned neighborhood integrated to mainly focus on the protection and use of natural resources, green technology, and green practices that aim to preserve the environment, safety and general welfare of the population. This definition is supported by Ho (2011, inwww.mdpi.com/journal/sustainability) who defined the green neighborhood as a design that considers the rate of harm and hazard reduction to the environment, such as global warming and pollution, because of high gas emission to preserve the ecological environment and provide a healthier lifestyle.

Based on Federal Department of Town and Country Planning (2011), a green neighborhood is defined as an area planned and designed in an integrated manner with the priority given to protection and consumption of natural resources with the application of green technology and recycling. The establishment of the Green neighborhood seeks to preserve the environment, reduce the ecological footprint, reduce the production of carbon emission, to improve public health, safety as well as the general welfare of city dwellers.

With the implementation of the green neighborhood, a concept plan and design are more structured, organized and manageable as they help to reduce the complexity into a less complex part (Luederitz et al., 2013, in www.mdpi.com/journal/sustainability). Green neighborhood concept includes the facilitation of accessibility, green network connectivity, green neighborhood buildings, neighborhood safety, highly-mixed use buildings, medium density, healthy neighborhood, suitability of design concept, time-saving and the shortening of distance to the nearest facility and public transport (Rosly, 2010, inwww.mdpi.com/journal/sustainability). Thus, people can save traveling time from one place to another, especially when commuting to work. Besides shortening traveling time, this concept also helps to improve social interaction among people and to satisfy people's needs (Qureshi \& Ho, 2011, ditto).

Publications on the impact of green neighbourhood started in early 1990 with the impact on the environment, followed by social studies among people of various age groups (Givoni, 1991; Phillipson et al., 1999; Taylor et al., 1998, ditto) and property value (Bolitzer \& Netusil, 2000; Hobden et al., 2004, ditto). Results indicated that children and adult tend to spend more time i.e. two times higher, carrying out activities in a green space compared to a less green space. However, children need adult supervision in some of the activities (Taylor et al., 1998, ditto). Studies on the green impact on property value were carried out by various scholars, which show the positive impact of the green neighborhood. 
Table 1: The summary of literatures on the impact of green neighbourhood (as in www.mdpi.com/journal/sustainability)

\begin{tabular}{|c|l|l|}
\hline Year of publication & \multicolumn{1}{|c|}{ Author(s) } & \multicolumn{1}{|c|}{ Focus } \\
\hline 2004 & Hobden et al. & Property value \\
\hline 2000 & Bolitzer \& Netusil & Property value \\
\hline 1999 & Phillipson et al. & Order people's experiences of community life \\
\hline 1998 & Taylor et al. & $\begin{array}{l}\text { The spending of more time in green spaces } \\
\text { among adults and children }\end{array}$ \\
\hline 1991 & Givoni & $\begin{array}{l}\text { The impact of urban planted areas: public } \\
\text { parks and private planting around individual } \\
\text { buildings }\end{array}$ \\
\hline
\end{tabular}

\begin{tabular}{|l|l|}
\hline \multicolumn{1}{|c|}{ Conventional Neighbourhood } & \multicolumn{1}{c|}{ Green Neighbourhood } \\
\hline $\begin{array}{l}\text { Building, infrastructure and utilities } \\
\text { development of are not environmental } \\
\text { friendly. }\end{array}$ & $\begin{array}{l}\text { Apply green approaches in buildings, } \\
\text { infrastructure, utility and built environment as } \\
\text { a whole. }\end{array}$ \\
\hline $\begin{array}{l}\text { Wasteful use of resources and over- } \\
\text { dependence on natural resources. }\end{array}$ & Practice efficient management of resource. \\
\hline $\begin{array}{l}\text { Private transport oriented. Public } \\
\text { transportation system are not integrated. }\end{array}$ & $\begin{array}{l}\text { Transit oriented development with integration } \\
\text { of multiple transportation mode, supported } \\
\text { by variety of facilities. }\end{array}$ \\
$\begin{array}{l}\text { Lifestyle: private automobile oriented and } \\
\text { making multi trips }\end{array}$ & $\begin{array}{l}\text { Lifestyle that reduces making unnecessary } \\
\text { trips, promotes walkability, narrower/skinnier } \\
\text { streets. }\end{array}$ \\
\hline $\begin{array}{l}\text { Priority given to greenfield development, } \\
\text { encouraging sprawl. }\end{array}$ & $\begin{array}{l}\text { Priority given to brownfield/infill site to } \\
\text { conserve land and energy resources. }\end{array}$ \\
\hline
\end{tabular}

Source : Federal Department of Town and Country Planning Ministry of Housing and Local Government of Malaysia (2011)

\section{ii. Sustainability}

Sustainability refers to the ability to preserve and retain. According to Luederitz et al. (2013, in www.mdpi.com/journal/sustainability), sustainable planning is urgently needed due to deficits in environmental quality, loss of plant and animal species, and climate change. Zone of sustainability is the union of economic, environment and social factors (Salonena \& Åhlberg, 2013, ditto).

a. From global perspectives, Chiesura (2004), discovers that green space, is key to the sustainability concept. Green spaces help develop positive emotional, sociology and psychology, include reducing stress. Mahmoud and El-Sayed (2011, ditto) state that in Egypt, green spaces and network improvement connect people that focus on promoting economic and the value of land towards improving the quality of life.

b. In Malaysia, planning guidelines focus more on sustainable development for green urbanism. The Government's efforts have helped to ensure that such development is carried out in an environmentally friendly condition. Green practices within an urban community also implement green activities supported by green technology towards addressing issues of global climate change (JPBD, Ministry of Housing and Local Government, 2011.)

\subsection{Factors That Contribute To Green Neighbourhood}

The green neighborhood is one of the important elements in the sustainable city to increase economic, environment and social quality in the area. In designing green, sustainable city, proper planning and implementation are required. A Proper consideration for a future greener environment needs to be prioritized based on all the below factors:-

\section{a. Walkability and Connectivity}

Green, walkable zone designs are necessary (Park et al., 2013) to preserve greenery and reduce carbon emission. According to Krambeck (2006 in Park et al., 2013), the main factors to be taken into account in green, walkable zone designs are safety and conduciveness of walkable area for pedestrians.

Many metropolitan cities such as Paris and New York have set up thoroughfares and streets to public spaces to encourage people to walk (Ng et al., 2012 in Park et al., 2013) because when people walk, the use of motor vehicles is less, thus reducing carbon emissions. Furthermore, walking is healthy, and it fosters social interactions among residents.

Hence, green, walkable zone networks should be easy to access, creating a comfortable walking experience when people move around especially to public amenities, infrastructure, and services (Mohd. Khir, 2012, in S Nurul Akmal et al., 2014). McNally (2010. in www.mdpi.com/journal/sustainability) states that the most preferred radius for walking is five (5) minutes. On the contrary, in Malaysia, 
the walking radius in green townships is at least ten (10) minutes (Rosly \& Hashim, 2011, in S Nurul Akmal et al., 2014). However, to maintain good health, people are encouraged to walk a longer distance.

In Portland, United States, the green network has been found to be very helpful to sustain and protect natural resources aside from linking the area to the green space (Rhew et al., 2011 in S Nurul Akmal et al., 2014 ). City of Dawson Creek (2008, ditto) argues that trees should be planted at least on one side of the street to protect people from sunlight so that they feel more comfortable when walking.

\section{b. Safety Zone}

Safety is defined as being safe from any danger, harm or risk that can be prevented from happening (Ding et al., 2014 in www.mdpi.com/journal/sustainability). In a neighborhood, security is crutial to improve social life (Annerstedt et al., 2012 , www.mdpi.com/journal/sustainability). Cochrane et al. (2009, ditto) highlighted factors such as road, the traffic condition and the influence of illegal activities on community events.

According to Park et al. (2013), Koreans usually feel insecure due to various factors such as difficulties faced in walking areas, cars, and crosswalks. Slippery sidewalks and dark walking areas are very dangerous especially during rainy and snowy days. Besides, parking of vehicles near sidewalks is also dangerous. This problem can be resolved by parking cars away from the sidewalk. Therefore, neighborhood environment should be friendly to people of all ages including those with disabilities (Zaharin, 2013, ditto). In Asian countries, the main issue is the increasing amount of $\mathrm{CO} 2$ that pollutes the air. Individuals in Hanoi tend to be exposed to such pollution that, in the long term, may ruin their health (Saksena et al., 2008, ditto). Therefore, in urban planning, plants are essential for human health (Mitchell \& Popham, 2008, ditto). Kowarik et al.(2011, ditto) suggested that small plants be planted at roadsides because it is not only cheap but also effective in improving air quality.

\section{c. Green Infrastructure}

People's perception of a green neighborhood is dependent on the quality of its infrastructure. A park is a recreation place for people and a habitat for wildlife. Park et al. (2013) highlighted the infrastructure elements which include sidewalks, shops, kiosks, sidewalk furniture, trees, electric wires, street lighting and parking spaces.

Leather et al. (2011, ditto) found inadequate facilities such as uncovered drainage along sidewalks, signage problems, and issues of crosswalk connecting to buildings. Greenways are an important role for a green city to connect people and places (Walmsley, 1995, ditto). Signage should be clear because it helps people find their way around ( $\mathrm{Ng}$ et al., 2012, ditto). Ismail (2013, ditto) argued that street art and cultural events can attract tourists and pedestrians and make a city more lively. Meanwhile, Sugiyama et al. (2013, ditto) discovered that people who live in a neighborhood with many green spaces tend to walk more at the recreation park and maintain their fitness compared to those living in an area without green space.

In New York, the mayor has redesigned the roads and closed some roads to make public space more livable and safe (Ng et al., 2012, ditto). For example, Times Square is now known as one of the busiest public spaces in New York (Ng et al., 2012, ditto). Green infrastructure helps promote a healthier lifestyle (Tzoulas et al., 2007, ditto).

\section{d. Mixed Use Development}

Mixed-use development is a mixture of land uses with many different functions of buildings. Figure 1 shows the mixed-use development of residential, workplace, shopping mall, recreational and educational facility in one neighborhood, and mono use. With the implementation of mixed-use development, the city will be more livable and can sustain the environment.

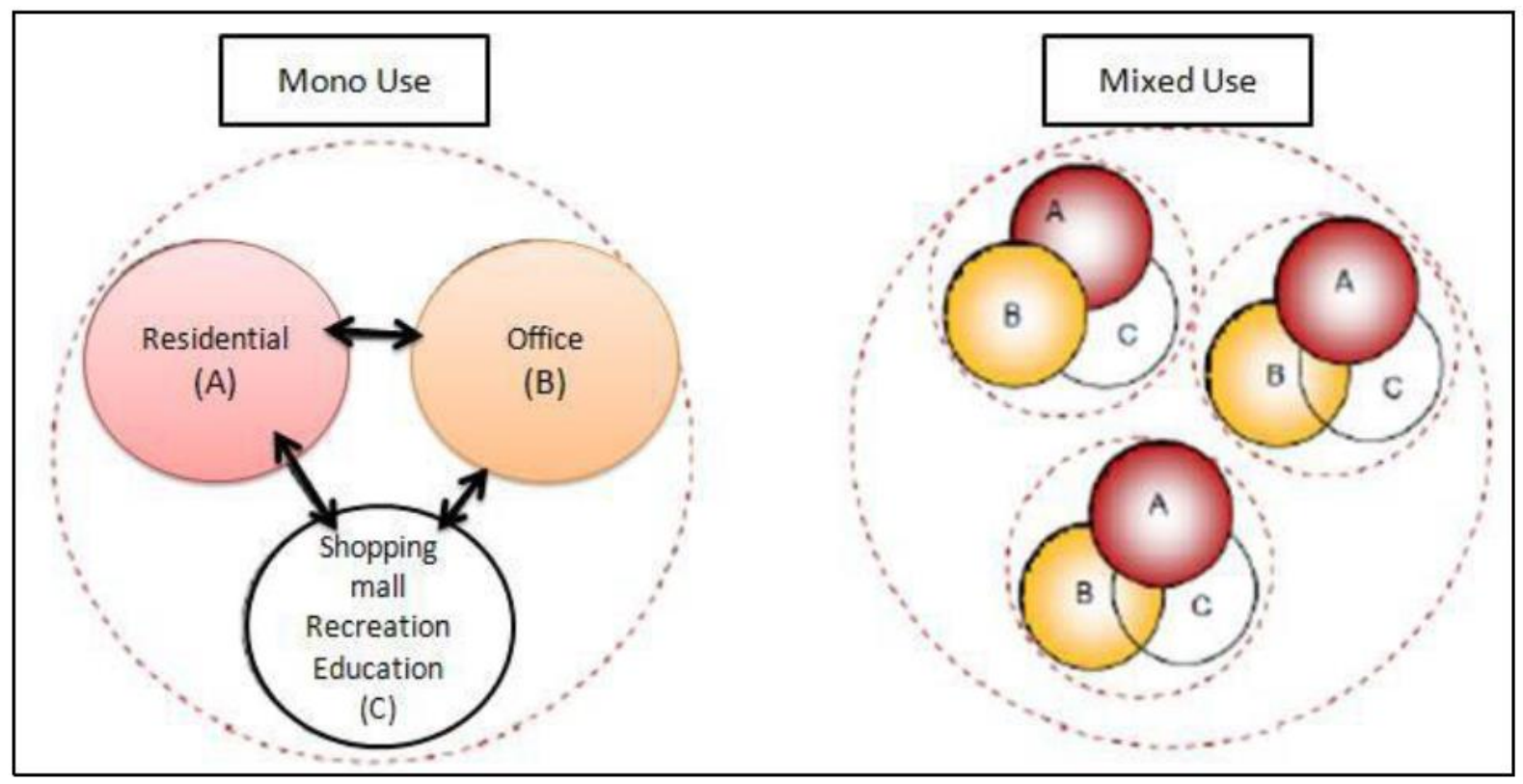

Figure 1: Mixed use and mono use in neighbourhood development Source : Arshad 2012 in www.mdpi.com/journal/sustainability) 
Arshad (2012) Proposed vertical mixed development where the ground floor is for retail, the middle is for office space, and the upper part is for residence. Rosly and Hashim (2011) stated that one-floor area should fill-up at least 15 percent of a building for the business purpose. On the other hand, education facility should be located at the corner of the neighborhood so that everyone can have equal access.

\subsection{Other Specific guideline of a green neighborhood.}

Green Neighbourhood Design includes a suitable size, density and mixed land use, a variety of housing types Street Network, Transit Services, Streetscape, Public Open Space and Neighbourhood Centre and local food production.

a) Green Infrastructure consists of Rainwater Harvesting, Rain Garden or Bioretention Roof, Top Garden, Permeable paver and On-Site Renewable Energy. Neighbourhood Size is a walkable scale - with an at least 10 minute's walk to main community facilities and should not be more than 125 acres.

b) Neighbourhood density, lot sizes and housing types may be varied, but the average gross density of the developed area should be at least 12 units per acre (medium density). A Low-Density Component in development should be located at the periphery of the neighborhood.

c) The composition of mixed land use and some non-residential component to support neighborhood's self-sufficiency with minimum $15 \%$ of floor space is for commercial activities. The school should locate at the edge of the housing area for future sharing of facilities and provision of public amenities should be by the JPBD Planning Guideline of Public Facilities (2011).

d) Street Network should encourage pedestrian connectivity by providing sidewalks and alleys, route options, for efficient internal movements and between adjacent neighborhoods. Discourage cul-de-sac with streets are relatively narrow and shaded by rows of trees.

e) Public open space is at least $10 \%$ of land use, and urban Park should be at the edge of the neighborhood.

f) Neighbourhood center provides a community center, design components that can create a sense of community and identity for a car free zone and encourage pedestrianization and cater for special needs and people with disabilities.

\subsection{Framework of Green Neighbourhood Application}

Research (Denish, 2011) shows that green neighborhoods reduce greenhouse emissions by 20 to $40 \%$ per person primarily. By contrast to the green neighborhood, the framework addresses the sustainability of an area using a predefined set of criteria and assessable indicators.

The objectives of the framework provide national consistency and a common language around the definition of best practice, sustainable communities, encourage innovation and excellence in our approach to creating communities of the future. They promote integration and collaboration across the spectrum of sustainability issues relating to sustainable communities, facilitate stakeholder engagement.

The framework is aspirational and visionary. It provides a high-level framework for structuring sustainability actions and ideas for projects. The framework serves to enhance that process and provide a mechanism to utilize best practice approaches to delivering sustainable outcomes. However, the reference framework for green neighborhood city towards sustainability are as below:-

\section{a. Mitigate Climate Change}

Cities emit significantly and growing amounts of greenhouse gasses (GHGs) - accounting for 37-49\% of total global GHG emissions (IPCC 2014). The International Energy Agency's projections indicate that urban energy-related GHG emissions will rise from around $67 \%$ today to $74 \%$ by 2030 (IEA 2008). Without waiting for global policies on climate change, some cities have started to take action. Cities can thus serve as "centers of policy ingenuity" that drive local energy and climate action plans. To promote their efforts towards reaching national and European targets, they can report their $\mathrm{CO} 2$ emissions on a voluntary basis and commit to complying with strong $\mathrm{CO} 2$ reduction targets. Cities implement their plan through - using their planning and taxation powers to encourage smart urban planning, energy-efficient buildings, renewable energy and district heating. - increasing energy efficiency on their building stock and more generally in the public realm; - encouraging local renewable energy sources and energy efficiency, including combined heat and power generation, by including criteria in their contracts with ESCOs (Energy Service Companies). - Developing innovative financing instruments with private and public partners. Raising awareness among citizens, and providing a contact point for advice, technical and financial audits to reduce energy consumption, especially for energy retrofitting thus encouraging sustainable production and consumption, as well as sustainable mobility and waste prevention.

\section{b. Protect, Restore And Enhance Biodiversity And Ecosystems}

Over the past 50 years, ecosystems have changed more rapidly and extensively than in any comparable period in human history. Globally, populations of fish, birds, mammals, amphibians, and reptiles have declined by 52 per cent since 1970; and freshwater species have suffered a 76 per cent decline - an average loss almost double that of land and marine species. Threats to biodiversity in Europe are mainly due to habitat loss as a result of agriculture intensification, including the use of pesticides and fertilizers, urban development, increased the frequency of fires and climate change. The basis of the approach is the four pillars of identifying green and blue "corridors" and "nodes" of the green infrastructure to be protected from development. This includes avoiding urban sprawl 
and soil sealing by improving the quality of life in already urbanised areas and taking financial measures to promote brownfield regeneration

Nature in the urban environment can offer multiple services and benefits: increasing well-being and quality of life, reducing the heat island effect and the quantity of runoff water, improving the air quality, but also attracting businesses or offering opportunities for recreation. Last but not least, ecosystems provide supporting services, like soil formation, photosynthesis, nutrient cycling and the conservation of gene pools that are necessary to sustain almost all other ecosystem services. These services need not only to provide enough surface areas for habitats, including on roof and walls, but also a diversity of habitats and species within the city.

\section{c. Reduce Pollution}

Since the start of the industrial revolution in the 19th-century, environmental pollution has grown into a global transboundary problem that affects air, water, soil and ecosystems, and is linked directly to human health and wellbeing. A substantial proportion of the EU's population is exposed to levels of air pollution, including indoor air pollution that exceeds the World Health Organisation's recommended standards. The urban population is exposed to a high level of fine particles, ozone, nitrogen oxide and mutagenic "polycyclic-aromatic hydrocarbons" concentrations resulting from the concentration of population and activities, especially through the burning of fuels for heating and cars and lorries. Citizens are exposed to volatile particles and present carcinogenic effects.

Cities have many levers to reduce outdoor air pollution in partnership with other levels of governance. In cases of pollution alert or crises, dedicated measures like free public transport, traffic restrictions, urban road tolls and low emissions zones can be implemented by local governments. Indoor pollution measures include raising awareness among citizens and tackling indoor pollution in public buildings, especially in schools and nurseries. Over the long term, the reduction of all types of pollution includes measures common to climate mitigation, renaturing cities and sustainable mobility.

\section{d. Adapt To Climate Change}

Rising sea levels, inland floods, and extreme weather events - in particular, increased heat - as well as increased droughts, often associated with water scarcity and air pollution, and the potential spread of diseases can have widespread negative impacts on people's health, livelihoods and assets. Cities are highly vulnerable to climate change, due to their high concentration of population and economic activities, public services and infrastructures. Local governments play an important role in adapting to existing and emerging threats facing their cities. They need to better understand their degree of exposure and vulnerability to potential impacts, so as to be able to assess the risks associated. The process has to involve key stakeholders, such as experts, service providers and the local community, with the aim of developing cross-cutting adaptation plans, with actions. They include managing the resilience of the community in urban planning and management. Developing strategic partnerships to organize crisis management for heat waves, droughts, flood events and their associated impacts, as well as post-crisis resilience. Capacity building and networking should be paramount for such a complex subject, and the identification of innovative sources of funding is of the utmost importance.

\section{e. Natural Resources Sustainable Management}

Resource-efficient cities combine greater productivity and innovation with lower costs and reduced environmental impacts. The sustainable management of natural resources and materials and waste prevention are thus not only significant environmental considerations but also key to the transition towards a green economy with the success of sustainable produced goods and services and the ensuing cost reductions. They are essential of the following nature: - organize separate collection and recycling of plastics, biowaste, glass, cardboard packaging, paper. - organize the recycling, upcycling, composting of collected products, including by allocating dedicated locations for these processes to take place in the planning documents. - develop specific actions targeted to the building sector to reduce construction and demolition waste (still increasing at the EU level). - encourage sustainable practices in forestry, agriculture, fishery and extractive activities by regulation, financial leverage and green procurement; - develop specific actions to protect the services offered by a healthy soil (food production, water retention and carbon storage etc.) guarantee a high level of environmental protection to essential habitats through biodiversity and ecosystem protection measures. - protect energy, clean air, and water resources, by reducing pollution, mitigating climate change and managing water sustainably. - Encourage the shift from "consumer" to "user" and from "owner" to "share."

\section{f. Protect, Preserve And Manage Water Resources}

Water resources are under increasing pressure in many parts of the world including in Malaysia. If agriculture is the leading source of pollution and water consumption, cities also have a role to play in: - maintaining and developing the vegetation cover and more generally avoiding soil sealing. A fully functioning soil stores $400 \mathrm{~mm}$ of precipitation per hectare. - ensuring excellent wastewater collection and treatment. - protecting wetlands and river basin from urban development. 


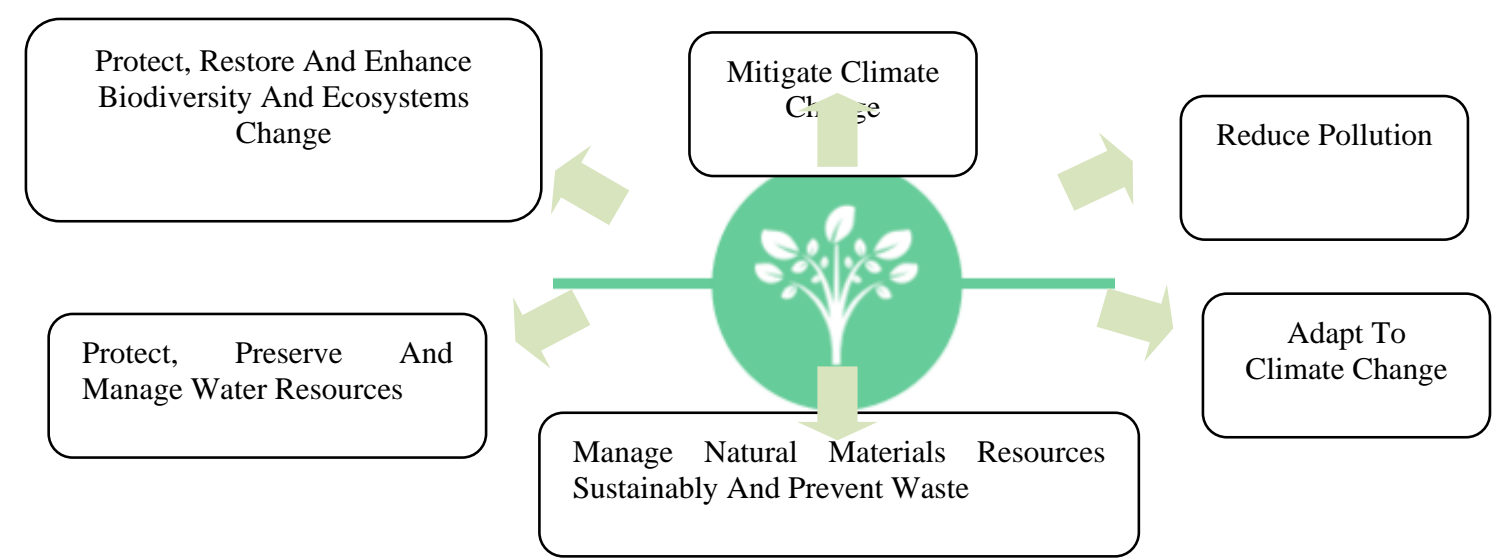

Figure 2 : Management of Renewable resouces

Source : The Reference Framework For Sustainable Cities: 5 Dimensions And 30 Objectives For A European Vision Of Tomorrow's Cities.

\subsection{Comparative Analysis of Framework}

Green neighbourhood as being discussed extensively in the literature can be divided into three main agendas namely sustainability, global climate change and design and planning application. The content analysis depicts the below patterns of argument with subjective and objective implications.

Table 3 : Sustainability Agenda

\begin{tabular}{|l|l|l|l|}
\hline Sustainablity Agenda & Criteria & Subjective and Objective Impacts & Evaluation remarks \\
\hline $\begin{array}{l}\text { Sources: EU, } \\
\text { International Energy Aenis(2011), }\end{array}$ & $\begin{array}{l}\text { Economy; } \\
\text { Girardet(2009/1999) }\end{array}$ & $\begin{array}{l}\text { Community economic development; } \\
\text { Social capital development and quality } \\
\text { of life; }\end{array}$ & $\begin{array}{l}\text { Valid and positive; sustainability as a } \\
\text { common goal for the better future for } \\
\text { all is widely accepted but the } \\
\text { Protection of biodiversity, renewable } \\
\text { implementation of the ideas seems } \\
\text { and non-renewable resources. }\end{array}$ \\
crawling in the development agenda
\end{tabular}

Table 4 : Climate Change Agenda

\begin{tabular}{|c|c|c|c|}
\hline Climate Change Agenda & Criteria & Subjective and Objective Impacts & Evaluation remarks \\
\hline $\begin{array}{l}\text { Sources: EU Vision, IEA(International } \\
\text { Energy Agency(2014), } \\
\text { IPCC(International Panel of Climate } \\
\text { Change, 2014), Park et al (2013) }\end{array}$ & $\begin{array}{l}\text { Reduce pollution emission; } \\
\text { Mitigation measures; } \\
\text { Protection of land, water and air } \\
\text { resources; } \\
\text { Safeguarding biodiversity and } \\
\text { ecosystem }\end{array}$ & $\begin{array}{l}\text { Increase and improve measures of } \\
\text { mitigation in natural resources } \\
\text { protection and add mechanisms } \\
\text { preventing further damages of climate } \\
\text { change; } \\
\text { Protection of biodiversity, renewable } \\
\text { and non-renewable resources. }\end{array}$ & $\begin{array}{l}\text { Valid and positive ; previously the } \\
\text { climate change agenda looks } \\
\text { unimaginable to be installed in reality }\end{array}$ \\
\hline
\end{tabular}

Table 5 : Design and Planning Application

\begin{tabular}{|l|l|l|l|}
\hline Design and Planning Application & Criteria & Subjective and Objective Impacts & Evaluation remarks \\
\hline Sources: EU Vision, JPBD(Jabatan & Walkability and connectivity; green & People-friendly design; & Valid and positive; \\
Perancang Bandar dan Desa, & infrastructure; safety zone; mixed use & Safe and protection of human being, & Built environment started with panning \\
and designing with the visions of the \\
Semenanjung Malaysia, Park et al \\
(2013), Arshad (2012), Ng et al (2012), \\
Qureshi \& Ho, 2011) & $\begin{array}{l}\text { streetscape; neighbourhood design; } \\
\text { public open space ; neighbourhood } \\
\text { center }\end{array}$ & $\begin{array}{l}\text { Positive interaction among inhabitants, } \\
\text { less pollutants; meeting the needs of } \\
\text { daily life; sense of community and } \\
\text { increase quality of life }\end{array}$ & $\begin{array}{l}\text { community at a small unit; Visioning } \\
\text { the people as the end receiver would } \\
\text { change the whole planning and design } \\
\text { paradigm }\end{array}$ \\
\hline
\end{tabular}

The above comparative analysis enhances the importance of the integration of the agenda in the green neighborhood to ensure its comprehensiveness and inclusive in nature and encompasses the good and valid agenda in the making. Thus the elements are equal threats in the dimension of criteria evaluation and assessment of the green neighborhood.

\subsection{Proposed Model of An Adaptive Model of Green Neighbourhood.}

The proposed model absorbs three main agendas as being widely discussed and argued in the literature by various experts, professionals, and researchers around the world. It embraces the agenda of sustainability, which targets the importance of safeguarding of present and future generation on the pertaining issues of environment, society, and economy. Green neighborhood established the nexus of sustainable agenda in its end product for the well-being of human beings, flora and fauna and the world's inhabitants. Reduction of pollution, carbon footprint, consumption of resources and protection of biodiversity some of the factors that 
consequently impact the global climate change. The two criteria mentioned earlier should embed to design and planning application in details of planning and designing aspects. This includes built environment components in a neighborhood such as an infrastructure, pedestrian, walkways, buildings, street network, landscaping and vegetation cover.

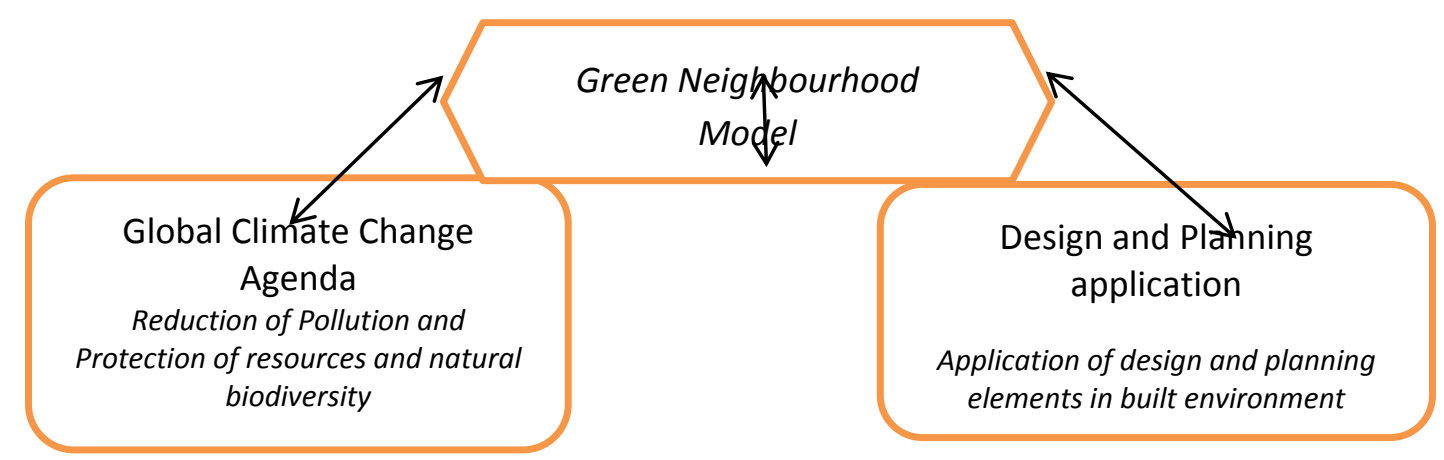

Figure 3 : The Proposed Model for Green Neighbourhood

\subsection{Conclusion}

The integration of micro and macro level of criteria is the essence in the green neighborhood agenda. It is paramount for the future decision makers, planners and designers adopt and implements the noble idea of seemingly global in nature to the small scale application as in the green neighborhood. The small and community-based green neighborhood are the real impacts on the ground that portrays the application and indicates the success or failure of the implementation. This indication provides vital information for further improvement and cycle of continuous upgrading the built environment for a better world in the future. Future research will focus on the impacts and application in zoom in application and assessment on the ground on the neighborhood scale for further enhancement of green neighbourhood agenda.

\section{Acknowledgement}

The authors would like to make a special mention to the Research Management Unit of UiTM, for granting LESTARI grant to make this research paper possible.

\section{References}

Article on Comparative Analysis of Material Criteria in Neighborhood Sustainability Assessment Tools and Urban Design Guidelines : Cases of the UK, the US, Japan, and Korea, retrieved on 15 November 2016 at www.mdpi.com/journal/sustainability.

Andras Reith and Melinda Orova (2015), Ecological Indicators : Do green neighbourhood ratings cover sustainability?, 48 (2015) 660-672, ABUD Engineering Ltd., 29. Lónyay St., Budapest 1093, Hungary.

A.Martos, R.Pacheco-Torres, J.Ordonez, E.Jadraque-Gago, (2016), Towards Successful Environmental Performance Of Sustainable Cities: Intervening Sectors. Department Of Engineering Construction And Project Management, University Of Granada, Spain.

Caroline Bergelin, Ayehlet Cooper, Desirae Hoffman, Fan Huang, Marcus Jones, Daniel Power, Julia Raskin (2012), Creating Sustainable Neighborhood Design for Legacy Cities: A New Framework for Sustainability Assessment.

Gary Haq and Anne Owen, (2011), York Green Neighbourhood Challenge A Targeted Social Marketing Approach for Community Pro-Environmental Behavioural Change, Stockholm Environment Institute.

International Panel on Climate Change (IPCC), 2014, UN

Jiyoung Park and Jungwon Yoon and (2015), Sustainability : Comparative Analysis of Material Criteria in Neighborhood Sustainability Assessment Tools and Urban Design Guidelines: Cases of the UK, the US, Japan, and Korea.

MIP, (2011), Federal Department of Town and Country Planning Department, Guideline And Framework For Green Township In Malaysia.

Nicola Wheeler (2011), National Housing Federation, Greener Neighbourhoods: A good practice guide to managing green space, The University of Sheffield.

Raji Banani, Maria M. Vahdati, Mehdi Shahrestani, Derek Clements-Croome (2016). The development of building assessment criteria framework for sustainable nonresidential buildings in Saudi Arabia, School of the Built Environment, University of Reading, UK.

S. Nurul Akmal, Z. Rosilawati, A. Faizah and M.N. Norzailawati, (2014) Factors that Contribute to Green Neighbourhood, International Journal of Property Sciences Vol. 4 Issue 1, Department of Urban and Regional Planning, Faculty of Built Environment, University of Malaya, Kuala Lumpur, Malaysia. 
Sharifi Ayyoob (2013), Sustainability At The Neighborhood Level: Assessment Tools And The Pursuit of Sustainability, Department Of Environmental Engineering And Architecture Graduate School Of Environmental Studies Nagoya University.

Tavel, Michael., (2012). Climate Responsive Urbanism. In Neis, Hans Joachim et. al, (Ed.), Generative Process, Patterns, and the Urban Challenge. Portland, OR: PUARL Press.

The EcoDistricts ${ }^{\mathrm{TM}}(2013)$ Framework : Building Blocks of Sustainable Cities

Wangel, J. et al.(2016), Environmental Impact Assessment Review 56 (2016) 200-213.

The Reference Framework For Sustainable Cities, 5 Dimensions And 30 Objectives For A European Vision Of Tomorrow's Cities

Green Healthy Neighbourhood Part 2 and Part 3, City of Chicago 